\title{
Evaluation of Selected Quince Genotypes (Cydonia oblonga Mill.) for Physico-chemical Attributes under Temperate Conditions of Kashmir Valley
}

\author{
Wasim H. Raja ${ }^{1}$, O.C. Sharma ${ }^{1}$, Sajad Un Nabi ${ }^{1}$, D.B. Singh ${ }^{1}$, Iqra Qureshi ${ }^{1}$, Lal \\ Chand $^{2}$, K.L. Kumawat ${ }^{1}$, S.N. Kirmani ${ }^{1}$ and Muneer Ahmad Sheikh ${ }^{1}$
}

${ }^{1}$ ICAR Central institute of temperate horticulture, Old Air Field Rengreth, Srinagar Jammu and Kashmir-190001, India

${ }^{2}$ ICAR Central Agroforestry Research Institute Jhansi-284003, Uttar Pradesh, India

*Corresponding author

\section{A B S T R A C T}

\section{Keywords}

Quince, Genotypes,

Physico chemical,

Colour, Firmness,

Pectin

\section{Article Info}

Accepted:

24 November 2018

Available Online:

10 December 2018
The Quince (Cydonia oblonga Mill.) is the only member of the genus Cydonia in the family Rosaceae. It is mostly used for culinary purposes and has great potential in processing industry. Quince genotype collections are maintained in quince block at ICARCITH, Srinagar. Physicochemical attributes play an important role in determining the nature and behavior of the fruit and their response to handling and processing. The present study was conducted during 2017-18, to evaluate ten genotypes of quince for physicochemical attributes both quantitatively and qualitatively. Our results confirmed the variability exists in, size, quality parameters like TSS, acidity, ascorbic acid, sugars and pectin. The significant differences were observed between the genotypes among different analyzed parameters. From our study, the genotypes CITH-Q-6 and CITH-Q-7, CITH-Q11 and CITH-Q-20 were found better in respect of various physicochemical parameters evaluated. The study will help in identifying the superior genotypes for processing and other uses in future.

\section{Introduction}

The Quince (Cydonia oblonga Mill.) is the sole member of the genus Cydonia in the family Rosaceae (which also contains apples and pears, among other fruits). Urdu name "Bahee Dana", Persian name "Beh", Greek name "Strythion", and Hindi name "Bihi". It is also called bamchount in Kashmir valley. In India, quince is mostly grown in Jammu and Kashmir and some parts of Himachal Pradesh in backyards and fence corners (Fiza et al.,
2008). Traditionally, quince after harvest is locally marketed and is used for culinary purposes and used for making different dishes in Kashmir valley and served usually in marriage functions. It is a deciduous tree that bears a pome fruit, similar in appearance to a pear, and bright golden-yellow when mature. Quince is too acidic, astringent and tough to be consumed as a fresh fruit. However, it can be consumed when cooked or when processed as jams, jellies and liquors (Roversi, 1983). Therefore quince fruit are widely used in the 
food industry, but rarely in the home. Because of less suitability for the direct consumption (Hričovsky et al., 2003) it is mostly used either cooked (Alvarenga et al., 2008) or preserved (Kyzlink, 1990). The fruit contains good amount of ascorbic acid (vitamin C), pectin (fibers) and minerals and is low in calories, carbohydrates, lipids and proteins (Kumar et al., 2013). The fruit has several phenolic compounds that contribute for its antioxidant capacity along with ascorbic and citric acid (Silva et al., 2004), as well as a large number of volatile compounds responsible for its characteristic fragrance (Tateo and Bononi, 2010). Quince is good for drying, making jam, fruit puree, stewed fruit, jelly, marmalade and candied fruit. It is known to have hypoglycemic action, antiinflammatory, antimicrobial, anticancer, antiallergic, antiulcer and works as brain and heart tonic. In Jammu and Kashmir, the existing variability in quince germplasm has not been exploited so far, as a result not a single known variety for commercial cultivation is available. Keeping in view above facts, current study was undertaken to study the variability in respect of quince genotypes in respect of physico chemical parameters to generate important information for identification superior genotypes for commercial cultivation, future breeding programme and processing potential.

\section{Materials and Methods}

The present study was conducted at the Research farm of ICAR-Central Institute of Temperate Horticulture (CITH), Srinagar, Jammu and Kashmir, India during the year 2017-2018. The experimental farm is located at $34^{\circ} 05 \mathrm{~N}$ latitude and $74^{\circ} 50 \mathrm{E}$ longitudes at an altitude of $1640 \mathrm{~m}$ above the mean sea level. The fruits to be used for analysis purpose were harvested at commercially maturity stage. Fruits were cleaned and washed properly to remove all adhering foreign matter such as dirt, dust and were sorted for immature and damaged fruits. Reagents used in the present study were of analytical grade.

\section{Physico - chemical analysis}

The various parameters, which include weight of the fruit, were measured by using Sartorius balance with accuracy of $0.001 \mathrm{~g}$. The length and diameter of each quince genotype was measured by digital Vernier caliper. Fruit firmness was recorded by digital firmness meter (Qualitest) and the colour characteristics in terms of $\left(\mathrm{L}^{*}, a^{*}\right.$ and $\left.b^{*}\right)$ and tint of quince genotypes were determined on sun-exposed side of each fruit with a chromameter Color Flex EZ Hunter lab USA. The seeds were separated manually from the ripe fruits and the determination of seed $(\%)$, Peel $\%$, edible matter $(\%)$, pectin $(\%)$ where done through method described by (Mazumdar and Majumder, 2003). The $\mathrm{pH}$, total soluble solids (TSS), total acidity, reducing sugar (\%),total sugar $(\%)$ and ascorbic acid were measured by a method as reported by The Association of Official Analytical Chemists (AOAC., 2012).

\section{Results and Discussion}

Physicochemical attributes play an important role in determining the nature and behavior of the fruit and their response to handling and processing. Quality of fruit is recognized by its physical characteristics, such as fruit weight, shape and colour which correspond to the external appearance of the fruit.

In the present study, maximum fruit weight $(227.75 \mathrm{~g})$, fruit length and fruit diameter were recorded in quince genotypes CITH-Q-07, CITH-Q-11(82.18mm), CITH-Q-07 (76.35 $\mathrm{mm})$ and minimum were recorded in genotype CITH-Q-08(118.57g), CITH-Q-08(58.22mm), CITH-Q-13(64.99mm) (Table 1), respectively the difference were found significant $(\mathrm{P}<$ 
0.05) among different genotypes. These findings are in conformity with who reported the variation of fruit wt, fruit length, and fruit dia among the quince genotypes. The differences in fruit weight might be due to different the genotypes are of seedling origin.

Fruit firmness in genotypes ranges from 61.47-82.53 RI. The maximum (82.53 RI) value of firmness was recorded in CITH-Q-10, and minimum (61.47 RI), value were recorded in CITH-Q-11 (Table 1), the difference might be due at difference in the maturity of fruit at the time of harvesting.

Among the other fruit parameters, highest edible matter $(91.48 \%)$, were recorded in quince genotype CITH-Q-08 and maximum peel percent $(6.04 \%)$ and seed percent $(5.22 \%)$ and were recorded in genotype CITH-Q-06. The difference in peel\% among the genotypes were found to be non significant.

Some genotypes were found superior then other genotypes on the basis of these findings, in terms of nearly all physical parameters. Our findings are in accordance with the findings of (Nawazish et al., 2015, Sharma et al., 2011).

Among the colour values for $\mathrm{L}^{*}$ ranges from 58.34 to 102.63 , the highest $L$ value (102.63) was recorded in CITH-Q-01and lowest value (58.34), was recorded in CITH-Q-13. Value for $\mathrm{a}^{*}$ ranges from -8.03 to 6.80 , the highest $\mathrm{a}^{*}$ value (6.80) was recorded in CITH-Q01and lowest value (-8.03) was recorded in CITH-Q-13), negative a* value were recorded in 04 genotypes. Value for $b^{*}$ ranges from 1.51 to 56.07 , the highest $b^{*}$ value (56.07) were recorded in CITH-Q-06 and lowest value (-1.51) was recorded in CITH-Q-1, one genotype is showing the negative value for $\mathrm{b}^{*}$ which indicates genotypes CITH-Q-01 have blueness in colour. The values for tint ranged between -29.57 to 3.25 (Fig. 1), the variations in colour ( $\mathrm{L}, \mathrm{a}^{*}, \mathrm{~b}^{*}$ and tint) might be due to difference in genotypes. The range of TSS among the genotypes was varies from 12.9 to $22.07 \mathrm{~B}^{\circ}$. The maximum TSS $\left(22.07 \mathrm{~B}^{\circ}\right)$ was observed in the genotype CITH-Q-13and minimum $\left(12.9 \mathrm{~B}^{\circ}\right.$.) were recorded in genotype CITH-Q-06 (Table 2). The evaluation of total soluble solids content (TSS) showed significant differences and had significantly higher contents of TSS than those previously reported by other authors (Sharma et al., 2011) which were around 15 Brix. However variations among genotypes and locations might be due to differences in plant genotype, maturity orchard and soil factors and environmental factors, as it was earlier studied by.

Acidity in genotypes ranges from $0.70 \%$ to $1.61 \%$, where maximum acidity $(1.61 \%)$ was recorded in genotype CITH-Q-06 and minimum $(0.70 \%)$ in CITH-Q-10 (Table 2). The content of titrable acidity of fruits is an important quality parameter and a key determinant of fruit taste. The results are in accordance with the findings of (Sharma et al., 2011) who recorded titrable acidity in Quince fruit in a range from 1.2 to $2.0 \%$.

The total sugar among the quince genotypes ranged from $8.83 \%$ to $10.42 \%$, where the highest total sugar value $(10.42 \%)$, was found in the genotype CITH-Q-05 and the lowest $(8.83 \%)$ was recorded in the genotype CITHQ-04 (Table 2).

The reducing sugar among the quince genotypes ranged from $4.83 \%$ to $6.09 \%$, where as the highest reducing sugar value (6.09\%) was recorded in CITH-Q-11genotype while the minimum (4.83\%) value in CITH-Q06 genotype. Quince fruit contains considerable amounts of sugars. Results regarding the sugars are in line with the earlier studies of (Sharma et al., 2011) who reported total sugars in different Quince cultivars ranging from $8.4 \%$ to $9.8 \%$. 
The ascorbic acid content among the quince genotypes ranged from 15.01 to 17.75 $\mathrm{mg} / 100 \mathrm{~g}$. The highest ascorbic acid (17.75 $\mathrm{mg} / 100 \mathrm{~g}$ ) was recorded in CITH-Q-20, while the lowest $(15.01 \mathrm{mg} / 100 \mathrm{~g})$ was recorded in CITH-Q-06 (Table 2). The variation in ascorbic acid among the genotypes was found to be non-significant and the variation in the ascorbic acid can be attributed to be effected by factors such as, genotype and maturity. While the findings of current study are well supported by the finding of (Sharma et al., 2011) who reported ascorbic acid in Quince fruit ranging from (16.8 to $17.6 \mathrm{mg} / 100 \mathrm{~g})$. The concentration of ascorbic acid can be influenced by various factors such as genotypes, and harvest practices (Lee and Kader, 2000).

The pectin concentration among the quince genotypes ranged from 1.05 to $1.92 \mathrm{~g} / 100 \mathrm{~g}$. The highest pectin $(1.92 \mathrm{~g} / 100 \mathrm{~g})$ concentration was recorded in CITH-Q4while the lowest $(1.05 \mathrm{~g} / 100 \mathrm{~g})$ was recorded in CITH-Q-05 (Table 2). The differences among the genotypes were found to be non- significant. Quince fruits are well-known for their high pectin substances, which makes the fruit suitable for the production of fruit spreads, mainly on the basis of their gelatinizing capability in acid environment and the presence of saccharose Kyzlink (1990). Out of the other core fruit species, a high content of pectin can be found out in apples and in our study the majority of Quince cultivars contained more than $1.05 \mathrm{~g} / 100 \mathrm{~g}$.

Among the evaluated genotypes the $\mathrm{pH}$ ranges from values 3.24 to 3.69. Maximum (3.69) $\mathrm{pH}$ was recorded in genotype CITH-Q06 and minimum (3.24) was recorded in genotype CITH-Q-11). $\mathrm{pH}$ variation was very small. The range of $\mathrm{pH}$ values found in the present study agreed well with previously reported by (Rodríguez- Guisado et al., 2009). The variation of $\mathrm{pH}$ in Quince fruits could be result of genotypes and other factors. The $\mathrm{pH}$ results found in this study are nearly similar to the finding (ranges from 3.3 to 3.36) reported by (Ali et al., 2015).

Table.1 Physical characteristics of quince genotypes

\begin{tabular}{|c|c|c|c|c|c|c|c|}
\hline $\mathbf{Z}$ & $\begin{array}{c}\text { Fruit } \\
\text { Wt. } \\
\text { (g) }\end{array}$ & $\begin{array}{c}\text { Fruit } \\
\text { length } \\
(\mathbf{m m})\end{array}$ & $\begin{array}{l}\text { Fruit } \\
\text { dia. } \\
\text { (mm) }\end{array}$ & $\begin{array}{l}\text { Firmness } \\
\text { (RI) }\end{array}$ & $\begin{array}{l}\text { Seed } \\
(\%)\end{array}$ & $\begin{array}{l}\text { Peel } \\
(\%)\end{array}$ & $\begin{array}{c}\text { Edible } \\
\text { matter } \\
(\%)\end{array}$ \\
\hline CITH-Q-01 & 194.77 & 66.39 & 72.69 & 81.53 & 4.42 & 5.11 & 90.47 \\
\hline CITH-Q-04 & 215.11 & 75.29 & 75.87 & 63.13 & 4.32 & 5.23 & 90.43 \\
\hline CITH-Q-05 & 190.64 & 77.96 & 70.02 & 63.10 & 4.48 & 5.69 & 89.84 \\
\hline CITH-Q-06 & 199.31 & 68.30 & 74.84 & 72.81 & 5.22 & 6.04 & 88.88 \\
\hline CITH-Q-07 & 227.75 & 77.32 & 76.35 & 64.87 & 4.14 & 5.57 & 90.25 \\
\hline CITH-Q-08 & 118.57 & 58.22 & 65.79 & 67.67 & 3.98 & 4.54 & 91.48 \\
\hline CITH-Q-10 & 213.55 & 79.96 & 75.39 & 82.53 & 4.95 & 4.82 & 90.22 \\
\hline CITH-Q-11 & 185.90 & 82.18 & 68.85 & 61.47 & 4.06 & 5.11 & 91.34 \\
\hline CITH-Q-13 & 182.21 & 81.76 & 64.99 & 68.30 & 4.23 & 5.67 & 89.95 \\
\hline CITH-Q-20 & 192.66 & 78.53 & 72.14 & 68.60 & 4.88 & 4.78 & 90.35 \\
\hline C.D $(p \leq 0.05)$ & 30.34 & 8.86 & 4.97 & 3.67 & 8.52 & NS & 8.63 \\
\hline $\mathrm{CV}$ & 9.21 & 6.93 & 4.85 & 2.78 & 6.89 & 18.76 & 8.41 \\
\hline
\end{tabular}

*NS-Non significant 
Table.2 Chemical analysis of quince genotypes

\begin{tabular}{|l|c|c|c|c|c|c|c|}
\hline Genotype & $\begin{array}{c}\text { TSS } \\
{ }^{\circ} \mathbf{B}\end{array}$ & $\begin{array}{c}\text { Acidity } \\
\%\end{array}$ & PH & $\begin{array}{c}\text { Ascorbic } \\
\text { acid } \\
\text { mg/100g }\end{array}$ & $\begin{array}{c}\text { Pectin } \\
\text { g/100g }\end{array}$ & $\begin{array}{c}\text { Reducing } \\
\text { Sugar } \\
(\%)\end{array}$ & $\begin{array}{c}\text { Total } \\
\text { Sugar } \\
(\%)\end{array}$ \\
\hline CITH-Q-01 & 13.87 & 1.60 & 3.60 & 16.96 & 1.38 & 5.20 & 9.65 \\
\hline CITH-Q-04 & 16.30 & 1.01 & 3.45 & 15.39 & 1.92 & 4.89 & 8.83 \\
\hline CITH-Q-05 & 20.43 & 1.07 & 3.45 & 15.92 & 1.05 & 5.20 & 10.42 \\
\hline CITH-Q-06 & 12.90 & 1.61 & 3.69 & 15.01 & 1.26 & 4.83 & 9.12 \\
\hline CITH-Q-07 & 15.40 & 0.92 & 3.67 & 17.07 & 1.13 & 5.14 & 9.51 \\
\hline CITH-Q-08 & 20.17 & 1.00 & 3.42 & 16.22 & 1.62 & 6.01 & 10.24 \\
\hline CITH-Q-10 & 15.67 & 0.70 & 3.68 & 15.22 & 1.39 & 5.23 & 9.80 \\
\hline CITH-Q-11 & 19.57 & 0.98 & 3.24 & 16.64 & 1.57 & 6.09 & 10.14 \\
\hline CITH-Q-13 & 22.07 & 1.00 & 3.36 & 17.42 & 1.07 & 5.39 & 10.13 \\
\hline CITH-Q-20 & 20.33 & 0.98 & 3.48 & 17.75 & 1.12 & 5.09 & 10.12 \\
\hline C.D(p<0.05) & 0.75 & 0.19 & 0.89 & NS & NS & 8.23 & 0.17 \\
\hline CV & 2.77 & 9.59 & 1.66 & 7.23 & 8.35 & 2.57 & 1.85 \\
\hline
\end{tabular}

*NS-Non significant

Fig.1 Colour characteristics of quince genotypes (L, $\mathrm{a}^{*}, \mathrm{~b}^{*}$ and tint) by colorimeter (Color Flex EZ Hunter

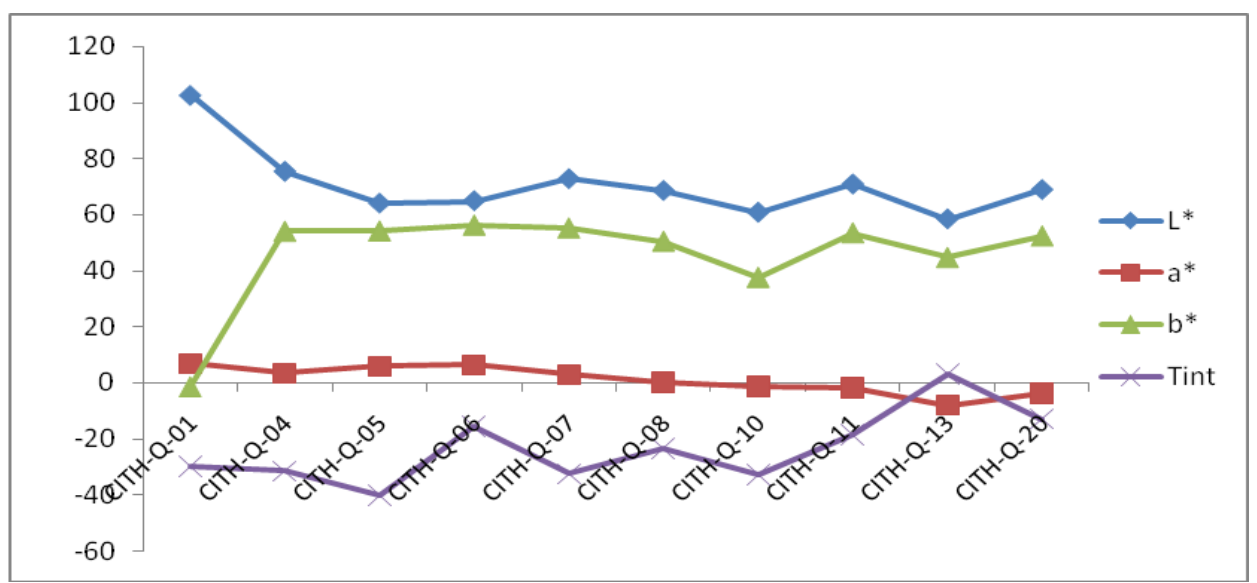

In conclusion quince has strong potential in processing industry for development of various post harvest products like, jam, jellies, marmalade, candies etc and physicochemical parameters play an important role in determining their response to processing. From evaluated genotypes CITH-Q-6 and CITH-Q-7, CITH-Q-11 and CITH-Q-20 were found better in respect of various physico chemical parameters and have great potential in processing industry. Among the evaluated genotypes, some are having sufficient nutrients including ascorbic acid, which can contribute to antioxidant activity. Our study can be utilized in future breeding programme for development of superior quince varieties having better quality in respect of various physico chemical parameters. Further among the evaluated genotypes elite ones can be used as mother plant for mass multiplication of plant with better quality and distribution among farmers for establishing quince orchards. 


\section{Acknowledgement}

Authors are highly thankful to Fruit science Laboratory assistants and ICAR-Central Institute of Temperate Horticulture, Srinagar for providing financial assistance to carry out the study.

\section{References}

Ali, N.Y., Abbas, A., Ali, M., Shahnawaz, N., Hussain, A. 2015. Physico-chemical Nutritional and Sensory Evaluation of Local Quince Fruit of Nomal Village, Gilgit - Baltistan, Pakistan. International Journal of Nutrition and Food Science, 4, 600-608.

Alvarenga A.A., Abrahao E., Pio R., Assis F.A., De Oliveira N.C. 2008. Comparison among marmalades produced from different fruit quince species (Cydonia oblonga Miller and Chaenomeles sinensis Koehne) and cultivars. Ciencia e Agrotecnologia, 32: 302-307.

AOAC. Official Methods of Analysis. 2012. Association of Official and Analytical Chemists, 17th ed., Gaithersburg, Md, USA.

F.Ahmad, Nawsheeba Wani, G. I. Hassan1, Gul Zafar, Ishtiyaq Ahmad Khan 2008.Variability in quince (Cydonia oblonga Mill.) population from baramulla district of Kashmir valley, Indian J. Genet., 68(2): 215-218.

Hričovský I., Řezníček V., Sus J. (2003): Jabloně a hrušně, kdouloně, mišpule. Príroda, Bratislava: 53-54.

Kumari, A., Dhaliwal, Y. S., Sandal, A.,
Badyal, J. 2013. Quality evaluation of Cydonia oblonga (Quince) fruit and its value added products. Indian Journal of Agricultural Biochemistry, 26, 61-65

Kyzlink V. 1990.Principles of Food Preservation. Elsevier, Amsterdam.

Mazumdar B.C and Majumder K 2003. Methods on Physico-Chemical Analysis of Fruits. University College of Agriculture, Calcutta University, 108109.

Rodriguez - Guisado I., Hernandez F., Melgarejo P., Legua P., Martinez R., Martinez J. J., 2009. Chemical, morphological and organo leptical characterisation of five Spanish quince tree clones (Cydonia oblonga Miller). Sci. Hortic. 122, 491 - 496.

Roversi, A. 1983. Frutticultura, XLV (12), 5964.

Lee, S.K., A.A. Kader. 2000. Postharvest Biology and Technology 20 207-220

Sharma R, Joshi VK, Rana C. 2011. Nutritional composition and processed products of quince (Cydonia oblonga Mill). Ind J Nat Prod Resour. 2:354-357.

Silva, B. M., Andrade, P. B., Valentão, P., Ferreres, F., Seabra, R. M., Ferreira, M. A. 2004. Quince (Cydonia oblonga Miller) fruit (pulp, peel, and seed) and jam: antioxidant activity. Journal of Agricultural and Food Chemistry 52, 4705-4712.

Tateo, F., Bononi, M. 2010. Headspace-SPME Analysis of Volatiles from Quince Whole Fruits. Journal of Essential Oil Research, 22, 416-418.

\section{How to cite this article:}

Wasim H. Raja, O.C. Sharma, Sajad Un Nabi, D.B. Singh, Iqra Qureshi, Lal Chand, K.L. Kumawat, S.N. Kirmani and Muneer Ahmad Sheikh. 2018. Evaluation of Selected Quince Genotypes (Cydonia oblonga Mill.) for Physico-chemical Attributes under Temperate Conditions of Kashmir Valley. Int.J.Curr.Microbiol.App.Sci. 7(12): 3172-3177. doi: https://doi.org/10.20546/ijcmas.2018.712.365 